\title{
POLISH, GREEK AND CYPRIOT CIVIL PROCEDURE TERMINOLOGY IN TRANSLATION. A PARAMETRIC APPROACH
}

\begin{abstract}
The paper discusses the problem of translating selected Civil Procedure terminology from Greek into Polish and from Polish into Greek. The research material includes corpora of normative acts and more precisely those, which regulate Civil Procedure of Poland, Greece and the Republic of Cyprus. The research methodology is based on the concept of parameterisation, according to which the legal linguistic reality becomes axiomatic. Then the set of relevant dimensions and parameters is extracted. The set of parameters are a tool where certain information is given: yes/no/none and thus a clear result of comparison between legal system bond terminology can be drawn up. The results of this comparative analysis provide highly regulated and available translation equivalents, which are essential when legal translation is performed within the frame of legal reality. Selected examples of use of these equivalents are given when discussing the results.

Keywords: legal terminology, legal translation, inter-legal translation, interlingual translation, civil procedure terminology, legal language, language of law, comparative study on legal terminology.
\end{abstract}

\section{Introduction}

Joseph (1995: 14) notices that "the translation of legal texts of any sort, from statute laws to contracts to courtroom testimony, is a practice, which stands at the crossroads of three areas of theoretical inquiry: legal theory, language theory (broadly defined, to include the interests not only of linguists but of rhetorical and textual theory as well), and translation theory". This statement confirms a widely accepted idea of the complex character of legal translation, which comes from the main idea of transferring one legal system into another (De Groot 1987, Šarčevič 1997 etc.) interdisciplinary character of legal translation, provokes scholars to investigate the legal translations form various perspectives. 
Among the various approaches to legal translation the aspect of legal communication and especially effective legal communication is worthy of consideration. The proposed approach has been investigated by a few scholars when considering legal translation. For instance Sandrini (2009) noticed, after Šarčevič (1997), that legal translation is similar to communication within the frame of law. In other words legal translation is strongly connected with the law and according to the author of the paper that can have two reasons: 1) legal text is the object of translation, 2) legal text (not primarily the object of the translation) regulates the procedure of translation. The cause 2) is increasingly frequent in current reality especially within UE where cooperation between judicial systems of various UE members is practiced every day. A relevant example of that situation may be the Treaty on European Union the Convention on $\mathrm{Mu}$ tual Assistance in Criminal Matters between the Member States of the European Union of 29th of May 2000. This act regulates and clarifies the method of delivering legal translation in EU member states and their organs, which exploit the mutual assistance procedure. In more specific situations, i.e. in Poland, internal legal acts may regulate the method of official legal translation provision. They concern certified translators and interpreters who provide their services for courts, prosecutors' offices etc. where translation of legal acts is part of their work. The profession of certified translators and interpreters is regulated by the Profession of Certified Translator Act of the 25th of November 2004 [Ustawa o zawodzie tlumacza przysiegtego z dnia 25 listopada 2004 r. (Dz. U. No 273, item 2702)]. It is worth to mention another legal regulation concerning certified translators and interpreters in Poland, which is the Ordinance of the Minister of Justice of the 24th of January 2005 on Remuneration for Certified Translators' and Interpreters' Services [Rozporzadzeniu $z$ dnia 24 stycznia 2005 r. w sprawie wynagrodzenia za czynności tłumacza przysiegłego]. Both the above mentioned acts concentrate on the inter-lingual and inter-legal communication between official legal organs, which need precise and distinct translation thus the paper suggests the proposal of strategy, which might be used when legal terminology is compared and finally chosen and used in translation.

Recently the final outcome of translation, a recipient of translation, is the trend noticed in scholars' investigations (Šarčevič 2000). This direction is based on the functionalists' approach, which has been observed in Reiss' work (1971: 32) and in Vermeer's works (1978) as well as in their joint work (Reiss and Vermeer 1984). Vermeer's Skopos Theory may be applied in some different ways. Firstly it can be employed during the translational process, 
and therefore to its outcome, secondly to the result of the translation and to its function, and finally to the method of translating and thus to the intent, which is behind it (Gonzales-Mathews 2003: 40). In the paper I make the assumption that the recipient and its features and needs determine the final outcome of translation. I wish to propose three basic models of legal translation based on the Skopos Theory ${ }^{1}$. These models are as follows:

1. Professional $\leftrightarrow$ professional, where the professional may be a lawyer, legislator, jurist.

2. Professional $\leftrightarrow$ semiprofessional, where the semi-professional may be a law student, legal translator, a person involved in legal theory or/and practice (i.e. businessman).

3. Professional $\leftrightarrow$ nonprofessional, where non-professional has no deeper connection with legal theory or practice.

In a multilingual environment these models may be multiplied because professionals, semiprofessionals and nonprofessionals may belong to various language communities. Language and communities (among them legal professionals' community) is based on Zabrocki theory of ethnic language communities and social communities (1963: 12-16), renewed by Bańczerowski (2001: 36-40). This assumption says that a group of people speaking one ethnic language are one language community. Among them there can be members of various social communities, for instance professional communities like legal professionals. from the other hand there are social communities which are independent from ethnic language. Legal professionals are one of communities of that kind. There is a possibility to distinguish many various social communities like for instance civil law community and common law community and their members can belong to one ethnic language community - Greek language community. The Zabrocki's theory of communicative communities can be successfully exploited to explain communication models (Gortych-Michalak 2013a \& 2013b: 91). More precisely, when concerning the investigated communicative situation, the community of language A (for instance the Polish language) or the community of language B (for instance the Greek language). Moreover professionals, semiprofessionals and nonprofessionals can be the objects of various legal systems both ethnic (i.e. Polish, Greek, Cypriot) and of various legal cultures (i.e. continental law, common law etc.).

In the paper, model 1 . is investigated more precisely and it is considered as the reference for comparative terminological study for translation purposes. This case is interlingual communication between legal professionals performed in two destinations and it can be illustrated by the following graphs: 


\section{Professional A $\Longleftrightarrow \quad$ Professional B}

\section{Graph 1. Communication between professionals}

In the investigated model A means community of Polish Language and B means community of Greek language.

As previously mentioned the professionals of various language communities may belong to various, ethnic legal systems: a - Polish, b - Greek, $\mathrm{c}$ - Cypriot. Then the above graph may be extended with new data as following:

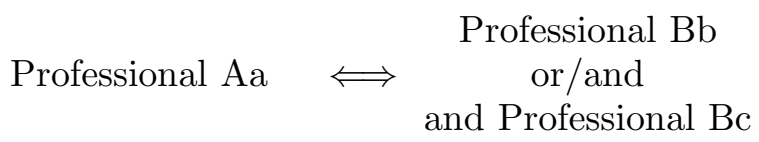

Graph 2. Communication between professionals of various ethnic legal systems

The investigated ethnic legal systems may belong to various legal cultures and in the investigated case they are: $\mathrm{X}$ - continental law and $\mathrm{Y}$ - common law and developing the above one may obtain the following graph:

$$
\text { Professional AaX } \Longleftrightarrow \begin{gathered}
\text { Professional BbX } \\
\text { or/and } \\
\text { and Professional BcY }
\end{gathered}
$$

Graph 3. Communication between professionals of various ethnic legal systems and of various legal cultures

It is worth mentioning that Professionals AaX and BbX (Polish and Greek) belong to one legal culture i.e. continental (civil) law and the Professional BcX belongs to another legal culture, which is common law. Another pattern of this specific communication event is the fact that interlingual communication is performed independently from legal systems and cultures between the Professional AaX and Professional BbX or/and Professional BcY. These notices will play a crucial role in the process of translation and especially in the process of provision of translation equivalents.

\section{Methodological remarks}

The purpose of the paper is to propose and to test the method of parameterisation when comparing legal systems of various states. As there are many differences between Poland, Greece and the Republic of Cyprus concerning language, legal system and culture, it might be vital to find 
a method, which could help lexicographers and translators to provide suitable terminological equivalents.

The methodology of the investigation is based on the theory of axiomatisation of the legal linguistic reality and the method of parameterisation postulated by Matulewska (2013, \& 2014). The research assumption of the paper is the statement that parameterisation of legal reality can be useful to determine differences in meaning of the compared term(s) originating from source and target language legal texts. Furthermore the results of the comparison can provide detailed information helpful in choosing an adequate translational equivalent. The comparison of parallel texts is the first step of the investigation and it comprises collection and choice of the normative acts of the same branch - civil law. It is worth to mention that the parallel texts, after Neubert (1996) and Delisle et el. (1999) have been recently called comparable texts (cf. Matulewska 2014). Then the axiomatisation of the legal linguistic reality is performed and the set of relevant dimensions is given. They are the common platform of comparison for terminology present in parallel normative acts. Comparative analysis is performed in tabular form where symbols "+" (meaning yes), "-" (meaning no) and "0" (meaning none/irrelevant) are used. The results of detailed analysis provide clear data to the translator who is to choose if the compared legal terms can suffice as equivalents for translation for professionals.

\subsection{Object of the analysis}

The object of the analysis is selected terms of Polish civil procedure in comparison with their Greek and Cypriot equivalents. The terms come from Polish statutory act, which is Code of Civil Procedure [Kodeks Postępowania Cywilnego]. The Greek equivalent statutory act is Code of Civil Procedure [Kodikas Politikis Dikonomias] and finally the Cypriot equivalent statutory texts are: Civil Procedure Rules (see List of normative acts referred to in this paper) - not translated officially into Greek (Hatzimihail 2013: 53) and Law of Civil Procedure Cap. 6 i.e. Laws, which have remained in force by virtue of Article 188 of the Constitution (Georgiades and Chrysostomides 2007: 2). The specific terminology to be compared are following terms: court of $1^{\text {st }}$ instance, court of $2^{\text {nd }}$ instance and supreme court which are present in the above mentioned normative acts and because of their parallel function, these terms can be compared.

\subsection{Objective of the analysis}

The objective of the analysis is to compare selected terms in the scope of legal and linguistic comparison. Thus the pragmatic and linguistic aspects 
are considered and shaped in the form of the set of dimensions of a certain parameter and moreover the dimensions are common for all investigated terms. All together they comprise a tool, which helps to estimate linguistic and pragmatic (legal) similarities and differences between compared legal terms. The results of the analysis are approximately " $0-1$ " logical results.

\subsection{Parametric approach}

The research methodology is based on the concept of parameterisation, according to which the legal linguistic reality becomes axiomatic. Then the set of relevant dimensions and parameters is extracted. The parameters consist of set of dimensions. The proposed parameters are divided into A) linguistics and B) pragmatic (legal).

A. Linguistic parameters

1. The author of the text

Relevant dimensions - possible authors/sources of law: legislator, lawyer-practitioner, lawyer-scholar, judge

2. Text delivery form

Relevant dimensions: written, oral

3. Text genre

Relevant dimensions: constitution, statutory act (law, code), judgement/sentence

4. Ethnic language

Relevant dimensions: Polish, Greek, other i.e. English - mentioned as language of civil procedure in Cypriot statutory acts according to Civil Procedure Rules, Order 58: Language

1. Subject to Rule 3 of this Order, any document served in Cyprus shall, if served on a Greek-speaking person, be in Greek, and if served on a Turkish-speaking person, be in Turkish, and in all other cases be in English.

2. Judgment and orders shall be entered in English. If a Greek or Turkish translation of a judgment or order is required for service in Cyprus, it shall be made by the Registrar of the Court.

3. Documents for the use of the Court presented by advocates who are barristers shall be in English. And documents intended for any such advocates may, even where the client for whom he is acting is Greek- or Turkish-speaking, be in English. Advocates other than barristers may bring themselves under this Rule by giving notice to that effect to the Registrar of the Court before which they appear, who shall post it up in the registry for public information.

5. Lect 
Relevant dimensions: language of statutory acts, language of legal practice, language of science of law, no legal lect (language for general purpose)

B. Pragmatic (legal parameters)

1. Text legal reality

Relevant dimensions: Continental Law, Common Law

2. Text validity

Relevant dimensions: valid, invalid

3. Branch of law

Relevant dimension: civil law, other

4. Sub-branch of law

Relevant dimensions; civil law, civil procedure

5. Application

Relevant dimensions: theory, practice,

6. Instance

Relevant dimensions: $1^{\text {st }}$ instance, $2^{\text {nd }}$ instance, extra instance

The aforementioned parameters are combined in one scheme (matrix), which, when imposed on certain term, are its linguistic and legal meaning and function. Comparison performed with the "tool" which is parameterization has the objective to explain in what extend certain terms are equivalent form language and legal perspective.

\section{Comparative analysis}

The analysis is performed on the terms meaning basic types of courts and more precisely on the types of courts seen from the perspective of instance in every ethnic legal system (Polish, Greek and Cypriot). The above parameters and their dimensions have been used to perform the analysis.

The table above presents the most immanent similarities and differences between Polish, Greek and Cypriot terms. From the linguistic point of view there is an important difference concerning ethnic language when taking into consideration the direction of translation. The Cypriot source texts provide equivalent Greek and English terms, which can be used immediately in Greek $\longleftrightarrow$ English translation where this certain term is required. On the other hand the difference based on the legal viewpoint comes from the type of legal reality in general, but specifically details i.e. branch of law, sub-branch of law and so on there is no difference. In these circumstances, from the functional point of view, one may consider Cypriot source term equivalent with Greek and Polish one and consequently it may be used in Greek $\longleftrightarrow$ Polish translation. 
Karolina Gortych-Michalak

Table 1

Court of $1^{\text {st }}$ instance. Parametric analysis

\begin{tabular}{|c|c|c|c|c|}
\hline Parameter & Dimension & Polish term & Greek term & Cypriot term \\
\hline & & $\begin{array}{l}\text { sąd rejonowy } \\
\text { (literally dis- } \\
\text { trict court) }\end{array}$ & 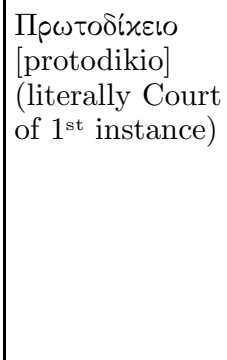 & 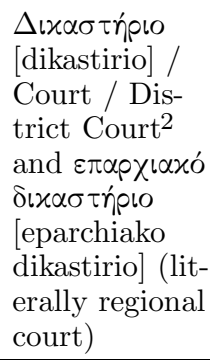 \\
\hline \multirow{4}{*}{$\begin{array}{l}\text { the author of } \\
\text { the text }\end{array}$} & legislator & + & + & + \\
\hline & $\begin{array}{l}\text { lawyer - } \\
\text { practitioner }\end{array}$ & - & - & - \\
\hline & lawyer scholar & - & - & - \\
\hline & judge & - & - & - \\
\hline \multirow{2}{*}{$\begin{array}{l}\text { text delivery } \\
\text { form }\end{array}$} & written & + & + & + \\
\hline & oral & - & - & - \\
\hline \multirow[t]{3}{*}{ text genre } & constitution & - & - & - \\
\hline & statutory act & + & + & + \\
\hline & judgement & 0 & 0 & 0 \\
\hline \multirow[t]{3}{*}{ ethnic language } & Polish & + & - & - \\
\hline & Greek & - & + & + \\
\hline & English & - & - & + \\
\hline \multirow[t]{4}{*}{ lect } & $\begin{array}{l}\text { language of } \\
\text { statutory acts }\end{array}$ & + & + & + \\
\hline & $\begin{array}{l}\text { language of } \\
\text { legal practice }\end{array}$ & - & - & - \\
\hline & \begin{tabular}{|l|} 
language of \\
science of law
\end{tabular} & - & - & - \\
\hline & no legal lect & - & - & - \\
\hline \multirow[t]{2}{*}{ text legal reality } & Continental Law & + & + & - \\
\hline & Common Law & - & - & + \\
\hline \multirow[t]{2}{*}{ text validity } & valid & + & + & + \\
\hline & invalid & - & - & - \\
\hline \multirow[t]{2}{*}{ branch of law } & Civil law & + & + & + \\
\hline & other & 0 & 0 & 0 \\
\hline
\end{tabular}


Polish, Greek and Cypriot Civil Procedure Terminology in Translation...

\begin{tabular}{|l|l|c|c|c|}
\hline \multicolumn{1}{|c|}{ Parameter } & \multicolumn{1}{c|}{ Dimension } & Polish term & Greek term & Cypriot term \\
\hline \multirow{2}{*}{$\begin{array}{l}\text { sub-branch of } \\
\text { law }\end{array}$} & $\begin{array}{l}\text { Civil (material) } \\
\text { law }\end{array}$ & - & - & - \\
\cline { 2 - 5 } & Civil procedure & + & + & + \\
\hline \multirow{2}{*}{ application } & theoretical & - & - & - \\
\cline { 2 - 5 } & practical & + & + & + \\
\hline \multirow{3}{*}{ instance } & $1^{\text {st } \text { instance }}$ & + & + & - \\
\cline { 2 - 5 } & $2^{\text {nd } \text { instance }}$ & - & - & - \\
\cline { 2 - 5 } & extra instance & - & - & + \\
\hline
\end{tabular}

Table 2

\section{Court of 2nd instance. Parametric analysis}

\begin{tabular}{|c|c|c|c|c|}
\hline Parameter & Dimension & Polish term & Greek term & Cypriot term \\
\hline & & $\begin{array}{l}\text { sąd okregowy } \\
\text { (literally re- } \\
\text { gional court) }\end{array}$ & 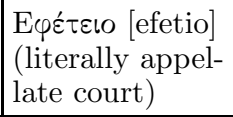 & $\begin{array}{l}\text { Court of Ap- } \\
\text { peal }^{3}\end{array}$ \\
\hline \multirow{4}{*}{$\begin{array}{l}\text { the author of } \\
\text { the text }\end{array}$} & legislator & + & + & + \\
\hline & $\begin{array}{l}\text { lawyer - } \\
\text { practitioner }\end{array}$ & - & - & - \\
\hline & lawyer scholar & - & - & - \\
\hline & judge & - & - & - \\
\hline \multirow{2}{*}{$\begin{array}{l}\text { text delivery } \\
\text { form }\end{array}$} & written & + & + & + \\
\hline & oral & - & - & - \\
\hline \multirow[t]{3}{*}{ text genre } & constitution & - & - & - \\
\hline & statutory act & + & + & + \\
\hline & judgement & 0 & 0 & 0 \\
\hline \multirow[t]{3}{*}{ ethnic language } & Polish & + & - & - \\
\hline & Greek & - & + & - \\
\hline & English & - & - & + \\
\hline \multirow[t]{4}{*}{ lect } & $\begin{array}{l}\text { language of } \\
\text { statutory acts }\end{array}$ & + & + & + \\
\hline & $\begin{array}{l}\text { language of } \\
\text { legal practice }\end{array}$ & - & - & - \\
\hline & $\begin{array}{l}\text { language of } \\
\text { science of law }\end{array}$ & - & - & - \\
\hline & no legal lect & - & - & - \\
\hline
\end{tabular}




\begin{tabular}{|c|c|c|c|c|}
\hline Parameter & Dimension & Polish term & Greek term & Cypriot term \\
\hline \multirow[t]{2}{*}{$\begin{array}{l}\text { text legal } \\
\text { reality }\end{array}$} & $\begin{array}{l}\text { Continental } \\
\text { Law }\end{array}$ & + & + & - \\
\hline & Common Law & - & - & + \\
\hline \multirow[t]{2}{*}{ text validity } & valid & + & + & + \\
\hline & invalid & - & - & - \\
\hline \multirow[t]{2}{*}{ branch of law } & Civil law & + & + & + \\
\hline & other & 0 & 0 & 0 \\
\hline \multirow[t]{2}{*}{$\begin{array}{l}\text { sub-branch of } \\
\text { law }\end{array}$} & $\begin{array}{l}\text { Civil (material) } \\
\text { law }\end{array}$ & - & - & - \\
\hline & Civil procedure & + & + & + \\
\hline \multirow[t]{2}{*}{ application } & theoretical & - & - & - \\
\hline & practical & + & + & + \\
\hline \multirow[t]{3}{*}{ instance } & $1^{\text {st }}$ instance & - & - & - \\
\hline & $2^{\text {nd }}$ instance & + & + & + \\
\hline & extra instance & - & - & - \\
\hline
\end{tabular}

When analysing the second example the same differences as in example have occurred, but in the parameter of ethnic language the difference is even clearer. The proposed Cypriot term is hyperonym of other judicial organ, which can be considered appeal court (according to aforementioned legal definition in the footnote). As in the example 1. the Cypriot equivalent is given in English, but there is no equivalent in Greek. When referring to pragmatic - legal parameters, this finding can obviously be explained. The Court of Appeal is not the proper name for any Cypriot court but it is a functional name. The Cypriot judicial system has only two levels and the function of the Court of Appeal is performed by the Supreme Court. The law concerning civil procedure and courts in civil procedure written in Greek has not include any equivalent term for the English one so the term exists only in the English legal communication of the Republic of Cyprus. In these circumstances when translating Polish term into Greek-

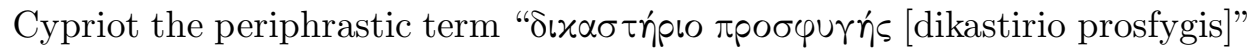
can be taken into consideration. This term comes from Inter Active Terminology for Europe database and was used in the act Council Regulation (EC) No. 1347/2000 of 29 May 2000 on jurisdiction and the recognition and enforcement of judgments in matrimonial matters and in matters of parental responsibility for children of both spouses and as it is considered by many Greek language users, it may be considered a sufficient translational equiv- 
Polish, Greek and Cypriot Civil Procedure Terminology in Translation...

alent. On the other hand translation from Greek-Cypriot into Polish should not be a difficult task because the Polish term, compared in the table above, is the correct equivalent for the Cypriot-Greek term.

Table 3

\section{Supreme Court}

\begin{tabular}{|c|c|c|c|c|}
\hline Parameter & Dimension & Polish term & Greek term & Cypriot term \\
\hline & & $\begin{array}{l}\text { Sąd Najwyższy } \\
\text { (literally } \\
\text { Supreme court) }\end{array}$ & $\begin{array}{l}\text { Apeíos Пáros } \\
\text { [arios pagos] } \\
\text { (literally } \\
\text { Areopagus) }\end{array}$ & 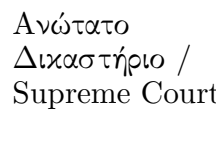 \\
\hline \multirow{4}{*}{$\begin{array}{l}\text { the author of } \\
\text { the text }\end{array}$} & legislator & + & + & + \\
\hline & $\begin{array}{l}\text { lawyer - } \\
\text { practitioner }\end{array}$ & - & - & - \\
\hline & lawyer scholar & - & - & - \\
\hline & judge & - & - & - \\
\hline \multirow{2}{*}{$\begin{array}{l}\text { text delivery } \\
\text { form }\end{array}$} & written & + & + & + \\
\hline & oral & - & - & - \\
\hline \multirow[t]{3}{*}{ text genre } & constitution & - & - & - \\
\hline & statutory act & + & + & + \\
\hline & judgement & 0 & 0 & 0 \\
\hline \multirow[t]{3}{*}{ ethnic language } & Polish & + & - & - \\
\hline & Greek & - & + & + \\
\hline & English & - & - & + \\
\hline \multirow[t]{4}{*}{ lect } & $\begin{array}{l}\text { language of } \\
\text { statutory acts }\end{array}$ & + & + & + \\
\hline & $\begin{array}{l}\text { language of } \\
\text { legal practice }\end{array}$ & - & - & - \\
\hline & $\begin{array}{l}\text { language of } \\
\text { science of law }\end{array}$ & - & - & - \\
\hline & no legal lect & - & - & - \\
\hline \multirow[t]{2}{*}{$\begin{array}{l}\text { text legal } \\
\text { reality }\end{array}$} & $\begin{array}{l}\text { Continental } \\
\text { Law }\end{array}$ & + & + & - \\
\hline & Common Law & - & - & + \\
\hline \multirow[t]{2}{*}{ text validity } & valid & + & + & + \\
\hline & invalid & - & - & - \\
\hline \multirow[t]{2}{*}{ branch of law } & Civil law & + & + & + \\
\hline & other & 0 & 0 & 0 \\
\hline
\end{tabular}




\begin{tabular}{|l|l|c|c|c|}
\hline \multicolumn{1}{|c|}{ Parameter } & \multicolumn{1}{c|}{ Dimension } & Polish term & Greek term & Cypriot term \\
\hline \multirow{2}{*}{$\begin{array}{l}\text { sub-branch of } \\
\text { law }\end{array}$} & $\begin{array}{l}\text { Civil (material) } \\
\text { law }\end{array}$ & - & - & - \\
\cline { 2 - 5 } & Civil procedure & + & + & + \\
\hline \multirow{2}{*}{ application } & theoretical & - & - & - \\
\cline { 2 - 5 } & practical & + & + & + \\
\hline \multirow{3}{*}{ instance } & $1^{\text {st } \text { instance }}$ & - & - & + \\
\cline { 2 - 5 } & $2^{\text {nd } \text { instance }}$ & - & - & + \\
\cline { 2 - 5 } & extra instance & + & + & + \\
\hline
\end{tabular}

The third analysed example confirms the differences, which have been noted when analysing the example 1 and likewise above, they differences concern the parameters of language and legal reality. It is also worth mentioning that all three terms (Polish, Greek and Cypriot) are Proper names, always written with capital letters. There is also a clear difference in the parameter "instance", which comes from the issue of two levels judicial system in Cyprus. The Supreme Court in Cyprus has the following jurisdictions, which fact has been taken into consideration (Republic of Cyprus, Supreme Court of Cyprus http://www.supremecourt.gov.cy/judicial/sc.nsf/DMLS Court_en/DMLSCourt_en?OpenDocument) for the needs of the present investigation: Appellate Court, Review of Administrative Decisions, Prerogative Writs, Admiralty, Election Petitions and Constitutional Matters. That is why the Cypriot term has two dimensions of the parameter "instance". For the scope of Polish $\longleftrightarrow$ Cypriot Greek translation the analysis highlighted many more similarities than differences that is why the terms may be considered translational equivalents.

\section{Findings coming from the comparative analysis}

The purpose of the research was to compare legal terms of various legal systems and languages. To perform the comparison the method of parameterisation was applied. Considering the complex character of legal language both linguistic and legal (pragmatic) parameters have been determined and exploited. The results of simultaneous comparison of three terms clearly present differences and similarities concerning certain parameters and thus they enable one to determine to what extend the terms are equivalent or not. The results of the comparative analysis presented similarities between 
Polish and Greek terms but simultaneously it presented differences between Polish/Greek and Cypriot equivalent from the pragmatic and linguistic perspectives. It has also revealed differences within the so called "Greek legal language" which comprise Greek legal language and Cypriot-Greek legal language. In the scope of translation these patterns are essential when performing interlingual and interlegal translation where "interlegal" means to convey meaning between legal realities.

\section{Conclusions}

The performed comparison of three groups of terms has been performed with the use of linguistic and pragmatic parameters. As previously mentioned the same matrix used for three terms simultaneously brought to light very important linguistic and pragmatic differences. They were metered logically yes - no - not determined and thus they can be clear answers to questions existing in translation practice. The method, because of its wide, possible application, can be used in lexicography, especially to prepare multilingual legal glossaries or dictionaries. As presented above the method can be useful when comparing and choosing adequate equivalent between source text terms of various ethnic languages, but simultaneously it can be useful when determining differences in the frame of one ethnic language used in various legal realities, for instance in Greece and in the Republic of Cyprus. In this perspective the method of parameterisation can be used by practitioners - translators and by scholars - lexicographers. As the presented research is part of the scientific project titled: Parametrisation of legilinguistic translatology in the scope of civil law and civil procedure, the author of the paper can give the assurance that till now the results are satisfactory and it is feasible to consider the method proper to investigate other branches of law.

The research financed from the research grant no. DEC-2012/07/E/HS2/00678, titled: Parametrization of legilinguistic translatology in the scope of civil law and civil procedure awarded by the National Science Centre of the Republic of Poland (Sonata Bis programme).

\section{N O T E S}

${ }^{1}$ It is worth to be added that the Theory was developed by Kierzkowska in pragmatic perspective (Kierzkowska 2008). 
2 English terms used the tables "Cypriot term" come from the act Civil Procedure Rules (95\% drawn in English, 5\% in Greek); the Greek terms are from Law of Civil Procedure Cap. 6 (in Greek).

3 There is no court of $2^{\text {nd }}$ instance in the Republic of Cyprus. Civil Procedure Rules. Order 35. Appeals. 1. In this Order "Court of Appeal" includes the Supreme Court and the President of a District Court when sitting on appeals. Thus the proposed term can be translationally equivalent from the functional point of view.

\section{R E F E R E N C E S}

Bańczerowski, J. 2001. The Linguistic Legacy of Ludwik Zabrocki. In S. Puppel (ed.) The Ludwik Zabrocki Memorial Lecture. Suprema lex: cognoscere, legere, dispputare, docere, 9-49. Poznań: UAM.

Delisle J. et al. 1999 (eds.). Translation Terminology. Amsterdam/Philadelphia: John Benjamins Publishing Company.

Georgiades, A., and Chrysostomides, G. 2007. Comparative Study of "Residual Jurisdiction" in Civil and Commercial Disputes in the EU National Report for: Cyprus. Lex Mundi Project. http://ec.europa.eu/civiljustice/news/docs/ study_resid_jurisd_cyprus_en.pdf. (accessed on 10th of May 2015).

Gonzalés-Matthews, G. 2003, L'Equivalence en traduction juridique, Thèse de Doctorat, Quebec City: Université de Laval. http://archimede.bibl.ulaval.ca/ archimede/fichiers/21362/21362.html (accessed on 10 ${ }^{\text {th }}$ of May 2015).

Gortych-Michalak, K. 2013a. Rola tłumacza w przekładzie polsko-greckim i greckopolskim. in D. Kondratczyk, A. Niewiadomski \& E. Walewska (eds.) Polski język prawny - media, społeczeństwo, edukacja, 9-19. Warszawa: Zakład Graficzny Uniwersytetu warszawskiego.

Gortych-Michalak, K. 2013b. Struktura polskich, greckich i cypryjskich aktów normatywnych Studium porównawcze $w$ aspekcie translatologicznym. Poznań: Wydawnictwo Naukowe Contact.

de Groot, G.-R. 1987. The point of view of a comparative lawyer. Les Cachiers de droit. vol. 28, no 4, 793-812. Quebec City: Université de Laval.

Hatzimihail, N. E. 2013. Cyprus as a Mixed Legal System. Journal of Civil Law Studies Volume 6 Issue 1 Summer 2013. Baton Rouge, Louisiana: Louisiana State University, Paul M. Hebert Law Center (CCLS).

Joseph, J.E. 1995. Interdeterminancy, Translation and the Law. In M. Morris (ed.) Translation and the Law 13-36. Amsterdam/Philadelphia: John Benjamins Publishing Company.

Kierzkowska, D. 2008. Tłumaczenie prawnicze. Warszawa: Wydawnictwo Translegis.

Matulewska, A. 2013. Legilinguistic Translatology. A Parametric Approach to Legal Translation. Frankfurt am Mein: Peter Lang Publishibg House. 
Matulewska, A. 2014. In Quest of Sufficient Equivalence. Polish and English Insolvency terminology in Translation. A Comparative Study. Studies in Logic, Grammar and Rhetoric 38 (51) 2014. Białystok: University of Białystok.

Neubert, A. 1996. Textlinguistics of Translation: The Textual Approach to Translation. In R. M. Gaddis (ed.), Translation Horizons Beyond the Boundaries of Translation Spectrum. Translation Perspectives IX, 87-105. Binghamton: Center for Research in Translation.

Reiss, K. 1971, Möglichkeiten und Grenzen der Übersetzungskritik. München: Max Hueber.

Reiss, K. and Vermeer H. J. 1984. Grundlegung einer allgemeinen Translationstheorie. Tübingen: Niemeyer.

Republic of Cyprus, Supreme Court of Cyprus http://www.supremecourt.gov.cy/ judicial/sc.nsf/DMLSCourt_en/DMLSCourt_en?OpenDocument (accessed on $10^{\text {th }}$ of May 2015).

Sandrini, P. 2009. The parameters of multilingual legal communication on globalized world. Comparative Legilinguistics. Vol 1/200. 34-48. Poznań: UAM.

Šarčevič, S. (1997), New Approach to legal translation. Hague/London: London: Kluwer Law International.

Šarčevič, S. 2000, Legal Translation and Translation Theory: a Receiver oriented Approach, Legal translation: history, theory/ies and practice. International colloquium University of Geneva, February 17-19, 2000: [proceedings]. Berne: ASTTI, cop. 2000.

Vermeer, H. J. 1978. Ein Rahmen für eine allgemeine Translationstheorie. Lebende Sprachen 3: 99-102. Leipzig: De Gruyter.

Zabrocki, L. 1963. Wspólnoty komunikatywne w genezie i rozwoju języka niemieckiego. Część I. Prehistoria języka niemieckiego. Wrocław: Ossolineum.

\section{List of normative acts referred to in this paper}

Civil Procedure Rules, Rules of Court made under the Civil Procedure Law, Cap. 7, the Mandamus Law, Cap. 23, the Dealings Between Merchants and Farmers law, Cap. 196, the Civil Wrongs Law, Cap. 9, the Cyprus Courts of Justice Orders and Laws 1927 to (No. 2) 1935, and Sections 37 and 40 of the Courts of Justice (Supplementary Provisions) Law, Cap. 12.

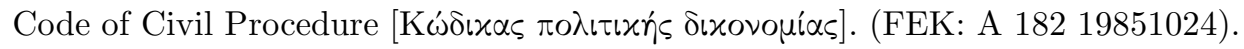

Council Regulation (EC) No 1347/2000 of 29 May 2000 on jurisdiction and the recognition and enforcement of judgments in matrimonial matters and in matters of parental responsibility for children of both spouses. Official Journal L 160, 30/06/2000 P. 0019-0036.

Law of $17^{\text {th }}$ of November 1964 Code of Civil Procedure [Ustawa z dnia 17.11.1964 r. Kodeks postępowania cywilnego] (Dz.U. $1964 \mathrm{nr} 43$ poz. 296).

Profession of Certified Translator Act of the $25^{\text {th }}$ of November 2004 [Ustawa o zawodzie tłumacza przysięgłego z dnia 25 listopada 2004 r. (Dz. U. No 273, item 2702)]. 
The Ordinance of the Minister of Justice of the $24^{\text {th }}$ of January 2005 on Gratification for Cetified Translators' and Interpreters' Services [Rozporządzeniu z dnia 24 stycznia $2005 \mathrm{r}$. w sprawie wynagrodzenia za czynności tłumacza przysięgłego] (Dz. U. of $26^{\text {th }}$ of January 2005).

Treaty on European Union the Convention on Mutual Assistance in Criminal Matters between the Member States of the European Union of 29th of May 2000. Official Journal of the European Communities. C 197 of Volume 43 of 12 July 2000. 